\title{
Stanley Milgram and Siegfried Lenz: An Analysis of Deutschstunde in the Framework of Social Psychology
}

Vladimir Tumanov

Department of Modern Languages and Literatures, Western University, London, ON N6A 3K7, Canada e-mail: vtumanov@uwo.ca

Neophilologus

An International Journal of Modern and Mediaeval Language and Literature

(2007) 91 (1): 135-148.

DOI: $10.1007 / \mathrm{s} 11061-005-4254-\mathrm{x}$ 


\title{
Stanley Milgram and Siegfried Lenz: An Analysis of Deutschstunde in the Framework of Social Psychology ${ }^{1}$
}

\begin{abstract}
:
Siegfried Lenz's novel Deutschstunde is analyzed on the basis of work conducted by two American psychologists: Stanley Milgram and Lawrence Kohlberg. The concept of duty and obedience to authority are considered as social phenomena that go beyond personal disposition. The article uses Milgram's famous obedience experiment in order to consider the literary depiction of psychological processes underlying compliance with orders to commit reprehensible acts. A comparison is made between Jens Jepsen, the fictional obedient policeman in Deutschstunde, and Paul Grueninger, a real policeman in wartime Switzerland, who refused to follow orders and saved many refugees at the Swiss-Austrian border.
\end{abstract}

${ }^{1}$ Published article here:

http://www.springerlink.com/content/3073813h7842248m/?p=00c7969943fa42e782e6 637d9df638e4\&pi=8 - ContactOfAuthor1 
Siegfried Lenz' Deutschstunde is a novel about a small-town German policeman, Jens Jepsen, who receives a peculiar order from Berlin toward the end of World War Two. He is supposed to prevent a "degenerate" artist, Max Nansen, from painting. Being a man of duty when it comes to his job, Jens Jepsen begins to carry out the order. The policeman is not a Nazi zealot or a sadist, but rather an intellectually unimpressive and emotionally dull man who takes his job very seriously. Initially Jens and the painter are friends, but once the painting interdiction comes in, the policeman's role takes over the policeman. Eventually Jens becomes personally obsessed with enforcing the painting interdiction and even burns some of Nansen's canvasses after the war is over!

This literary policeman can be contrasted with a real one. In 1940 Paul Grueninger, a Swiss officer of the law at the Austrian border, was dismissed from his job and deprived of his pension. He had been found guilty of disobeying instructions from the Swiss authorities by allowing Austrian refugees to enter Switzerland. Grueninger was very different from his colleagues and perhaps a minority of one since most other police officers knew how to follow orders unquestioningly (François Rochat: 91). The rarity of Grueninger's behavior points to the purpose behind Lenz' Deutschstunde. Lenz presents his fictional policeman as a reflection of the millions in Nazi Germany who also "merely" followed orders as they committed abominable acts. The question is why so many people acted like Jepsen and so few like Grueninger? One possible answer may be offered by social psychology.

Psychology features prominently in Deutschstunde because the novel is narrated by the policeman's son, Siggi Jepsen. Siggi is so disturbed by his father's behavior that the boy begins a quest to save Nansen's paintings. This eventually turns into an obsession causing Siggi to steal some paintings in order to protect them. Siggi ends up institutionalized on an island and scrutinized by psychologists from all over the world. However, the issue is 
whose behavior should be psychologized: Siggi's or Jens'? Although there is no denying that Siggi is disturbed, the novel appears to suggest that the psychologists' gaze is misdirected as Siggi points out himself: "Na gut, dann werde ich Ihnen sagen, warum ich auf der Insel bin. Weil keiner sich traut, dem Polizeiposten Rugbüll [Jens Jepsen - V.T.] ein Entziehungskur zu verordnen; der darf süchtig bleiben und süchtig seine verdammte Pflicht tun" (Lenz: 433). The validity of analyzing exclusively Siggi's mind is also questioned implicitly by the caricaturization of the psychologists around Siggi: "Boris Zwettkoff, der Amerikaner, war sehr zufrieden, als ich ihm auf die Frage, ob ich bei meiner Strafarbeit mitunter das Gefühl hätte, im Wasser zu stehen, durch Wasser zu waten oder in klarem Wasser zu schwimmen, ein glattes Nein anbieten konnte" (Lenz: 148). Robert H. Paslick refers to this as "the deflection of anxiety and guilt into formulae of harmless gibberish" (214), suggesting that psychological science is looking at the wrong subject.

A far more appropriate target of psychological study would be Jens Jepsen and through him German society as a whole. But Jens is never institutionalized or analyzed directly and ends up resuming his role as officer of the law once the war is over. Instead, Wolfgang Mackenroth, the psychologist attached to Siggi Jepsen, relies on information provided by Siggi in order to take a brief indirect look at the obedient policeman: "Was für den Polizisten ursprünglich einen, wenn auch außerordentlichen, Routineauftrag darstellte - die Überwachung des Malverbots -, wandelte sich auf Grund charakterologischer Eigenart, zu einer Zwangsvorstellung; für ihn wurde die Überwachung des Malverbots zu einer persönlicher Angelegenheit" (398).

The question here is the implications of Mackenroth's phrase "auf Grund charakterologischer Eigenart." Admittedly, Jens defines himself in terms of duty, so he is doubtlessly predisposed to obey authority. However, if this character trait were all that summed up Lenz's policeman, he would spring into action without a second thought. He would demonstrate unwavering zeal as 
soon as the order from Berlin is issued. That, as will soon be demonstrated, is not the case. And as for making the painting interdiction what Mackenroth calls "eine persönliche Angelegenheit," again, it must be noted that the obsessive state is reached by Jens Jepsen only gradually, and by no means from the start of Deutschstunde.

At this point let us turn to the controversial experiments conducted by the Yale psychologist Stanley Milgram from 1960 to 1963 and described in his seminal work entitled Obedience to Authority. Milgram wanted to understand how so many ordinary people could obey orders from the Nazi authorities - along the lines of what Jens Jepsen does in Lenz' novel. What made ordinary individuals commit extraordinarily reprehensible acts, support policies that went against age-old moral values and consider themselves to be normally functioning members of society (Milgram: 2)? Milgram turns to Hannah Arendt's book entitled Eichmann in Jerusalem and agrees with the author's conviction that "the prosecution's effort to depict Eichmann as a sadistic monster was fundamentally wrong, that he came closer to being an uninspired bureaucrat who simply sat at his desk and did his job" (5). This idea of "simply doing one's job" applies to the behavior of Jens Jepsen in Deutschstunde. Lenz' dimwitted policeman is also an "uninspired bureaucrat" who views his actions only in terms of his immediate duties. The question for Milgram was to what extent this ordinariness of evil could be borne out by experimental evidence.

Milgram brought people from different social strata to his lab and told them that they were going to participate in an experiment on human memory. Each one of them was to act as a "teacher" who would teach a "learner" (in fact Milgram's accomplice) something that had to be memorized. If the learner failed at a given memorization task, the teacher was asked to administer an electric shock. It all looked real because the learner was attached with electrodes to a fake electric shock machine. The teachers were told by the experimenter that the first few memory errors required low voltage 
punishment which elicited a minor reaction from the learner, e.g., "ouch!" But gradually, with every new learning error, the voltage was supposed to be increased until eventually, "at 285 volts [the learner's] response could only be described as an agonizing scream" (Milgram: 4). The experimenter's position of authority was established by the laboratory setting and the fact that the study was taking place at Yale University, an institution "which most subjects regarded with respect and sometimes awe" (Milgram: 66, cf. 93-7).

The results of the experiment were very disturbing and had enormous implications for understanding what happened in Nazi Germany:

Despite the fact that many [teachers] protested to the experimenter, a substantial proportion continued to the last shock on the generator. [...] Almost two-thirds of the participants fell into the category of 'obedient' subjects. They represented ordinary people drawn from the working, managerial, and professional classes (Milgram: 5).

Milgram conducted the experiment with various groups of people and altered the format of the situation. The study was repeated at other laboratories by other researchers with results similar to Milgram's. ${ }^{2}$ The shocking conclusion appears to be that monstrous deeds do not require monsters at every level. "Obedience [to authority] is a basic element in the structure of social life" (1), concludes Milgram with the implication that all those who cannot conceive of themselves as acting out this kind of amoral obedience should not feel too smug.

In Deutschstunde Lenz is very careful to stress that Jens Jepsen - however unpleasant he may be - is not evil. When the painting interdiction is first received by the dutiful policeman, Jens is embarrassed by it and tries to delay setting out for the painter's house: "Mein Vater ging hin und her und offenbar nach Gründen suchte, um seinen Aufbruch zu verzögern [...] bis er mit ärgerlichem Erstaunen feststellen musste, dass etwas Neues aus inm entstanden war, dass er sich gegen seinen Willen in einen vorschriftsmäßigen 
Landpolizisten verwandelt hatte" (Lenz: 20). Thus, even though Jens Jepsen is a bureaucrat for whom "orders are orders," his sense of ethical values has not atrophied. He is able to overcome this internal hindrance only by transforming himself, by becoming "etwas Neues" - something that he was not a moment ago. But this irritates and surprises him ("mit ärgerlichem Erstaunen") and does not appear natural in his mind ("gegen seinen Willen").

When the policeman finally does set out for the painter's house and arrives there in order to announce the painting interdiction, Jens' absence of personal zeal is further stressed in what he says to Max Nansen: "Warum glaubst du, Max? Warum sollst du aufhören zu malen?" (Lenz: 33). Therefore, at this point the policeman is far from standing behind the interdiction which puzzles him more than anything. To show that his personal bond with the painter is still intact, Jens adds: "Ich habe mir das alles nicht ausgedacht, Max, das kannst du mir glauben. Mit dem Berufsverbot habe ich nix zu tun" (Lenz: 334). When the situation becomes tense later on, as Jens begins to enforce the painting interdiction, and the painter becomes hostile toward Jens as a representative of Nazi power, the policeman still feels very ill at ease in his new role: "Ihr habt kein Recht dazu, sagte der Maler, und mein Vater darauf: Ich hab das nich [sic] geschrieben, Max, ich maß mir auch nix an, und er konnte seine Hände nicht daran hindern, eine Bewegung unbestimmter Hifllosigkeit zu machen" (Lenz: 72). Therefore, if Jens can be taken to stand for millions of average Germans under Hitler, the novel does not portray such people as deliberate evildoers. In the same way Milgram's subjects were themselves astonished as they ended up hurting the accomplice under instructions from a figure of authority.

The tension experienced by Jens Jepsen is similar to what Milgram found among his subjects. Many people in the obedience experiment protested against their task even while administering electric shock. The degree of protest varied, but the key issue here is that very few of Milgram's subjects 
calmly hurt the accomplice, although hurt him they did. They were all torn between two imperatives: "A conflict develops between the deeply ingrained disposition not to harm others and the equally compelling tendency to obey others who are in authority. The subject is quickly drawn into a dilemma, and the presence of high tension points to the considerable strength of each of the antagonistic vectors" (Milgram: 42-3, 76-7). In the case of Jens Jepsen the vector that wins out is the order to prevent Max Nansen from painting, i.e., obedience to authority. However, as the passages quoted above demonstrate, the policeman still experiences what Milgram refers to as "strain": "If the individual's submergence in the authority system were total, he would feel no tension as he followed commands [...]. Every sign of tension, therefore, is evidence of the failure of authority to transform the person to an unalloyed state of agency" (155).

In order to downplay any notion of inherent evil in Jens Jepsen, Lenz contrasts the "dutiful" policeman with the latter's wife Gudrun. She is presented as truly "demonic," sadistic and very much in tune with Nazi ideology, manipulating her husband at every step. Robert $\mathrm{H}$. Paslick writes: "Once given direction [Jens] becomes an automaton in the pursuit of his duty. The direction is determined by official orders, but the power behind his actions is supplied by his wife, Gudrun" (211). For example, Jens cannot bring himself to cane Siggi (who left the house without permission in the middle of a storm) without an external command which comes from Gudrun (Lenz: 55). The narrator makes it clear that the father is embarrassed by the need to hurt his son. Thus, before the first strike, we read: "Da zuckte mein Vater die Achseln, musterte mich verlegen, auch lustlos" (Lenz: 56, my italics - V.T.). Then, once the caning is over, Siggi sums up his father's spineless role: "Dann zerrte er die Bettdecke unter meinem Körper hervor, deckte mich zu und saß tatenlos auf dem Holzstuhl vor meinem Ozean, das Gesicht lauschend zu Schräge verzogen und hilflos, da er ohne Auftrag war und ohne Auftrag nur ein halber Mensch" (Lenz: $57)$. 
Behind the central Auftrag of the novel (the painting interdiction) is a whole edifice of Nazi ideology. However, it is not Jens, but Gudrun who actually consciously links the interdiction and Nazi esthetics. This is clear from the way she analyzes Max's art: "Wenn man sich so ansieht, welche Leute er malt: die grünen Gesichter, die mongolischen Augen, diese verwachsenen Körper, all dieses Fremde: da malt doch die Krankheit mit. Ein deutsches Gesicht, das kommt bei ihm nicht vor" (Lenz: 175). As Albrecht Weber puts it, Gudrun "gibt dem Stil ihre Idelologie" (69). It is, therefore, not surprising that Gudrun shares the Nazis' contempt for the mentally retarded as she recoils from a group of handicapped children in the town (Lenz: 369). Jens, on other hand, never thinks about such matters and especially about the paintings he is supposed to suppress or impound. He occasionally echoes Gudrun's views because she is a figure of authority, but generally he appears to be too simpleminded for the consideration of the political meaning behind his actions (cf. Murdoch and Read: 61). Jens Jepsen's concern has to do only with obedience: "Ungläubigkeit hielt inn da wohl fest, die unerträgliche Verblüffung darüber, daß der Mann [Max Nansen], der aus dem gleichen Ort stammte wie er [Jens] und deshalb die gleichen Voraussetzungen mitbrachte, nichts anerkannte, kein Verbot und keine Verfügung" (Lenz: 164).

Although in Jens' case, the obedience urge is exaggerated for artistic purposes, it is by no means an anomaly. Milgram tries to explain the extent to which the obedience urge is ingrained in most people as follows:

From his very first years [a person] is exposed to parental regulation, whereby a sense of respect for adult authority is inculcated. [...] As soon as the child emerges from the cocoon of the family, he is transferred to an institutional system of authority, the school. [...] The first twenty years of the young person's life are spent functioning as a subordinate element in an authority system, and upon leaving school, the male usually moves into either a civilian job or military service. On the job, he learns that although some discreetly expressed dissent is allowable, an underlying posture of submission is required for harmonious functioning with superiors (135-7). 
This inculcated need to obey authority appears to be the mechanism behind the transformation of Jens Jepsen's behavior. As the painting interdiction process continues, the policeman's initial tension and embarrassment gradually disappear, and Jens Jepsen starts to go about his task with more an more determination: "Mein Vater stand dem Maler ohne Verlegenheit gegenüber, es gelang ihm sogar, in seiner Haltung ungeduldiges Begehren auszudrücken. [...] Er sagte: Is in Berlin verfügt worden, das genügt" (73; emphasis mine - V.T.). Since this statement occurs rather early in on in the story, Jens still appears somewhat subdued. But the absence of his initial Verlegenheit is telling of the changes taking place. Later Jens begins to feel anger at the painter's disregard for authority and a certain amount of aggression is introduced into the policeman's position: "Aber inr [the likes of Nansen - V.T.] seid ja groß, ihr seid ja allen überlegen, für euch gilt nich, was für andere gilt" (Lenz: 222-3). Eventually, the policeman becomes so overtaken by his task that he ends up burning some of Max' paintings by the end of the novel (Lenz: 350).

The shift from viewing the painting interdiction as an embarrassing but necessary task to what happens later in the novel indicates an evolution of Jens' self-image. In this respect let us turn to Barry E. Collins' and Laura Ma's analysis of Milgram's work and consider what they refer to as "self-perception theory." Collins and Ma argue that we define ourselves among other things by observing our own behavior. It is obvious that we define others on this basis, but that we also form our own self-image in the same way may seem less selfevident. Collins and Ma ask what caused events like the Kristallnacht: inherent German anti-Semitism, a peculiar quirk of the "German mentality" or something else?

Participation in, say, Kristallnacht may have served the function of reaffirming and expressing the ordinary individual's sense of identity. This analysis is compatible with the assertion that the anti-Semitism of the person on the street caused the Holocaust (e.g., Goldhagen, 1996). The 
inclusion of self-perception theory (i.e., how our behaviors feed back into our own identities) in the present analysis also leads one to turn that (antiSemitism caused the Holocaust casual sequence) around. Self-perception theory, unlike Milgram's theory of the agentic state, would postulate that an individual would need to feel choice or responsibility for each anti-Semitic act in order for that act to feed back into an anti-Semitic self-view and public image. In other words, it may have been the cumulation of the concrete, behavioral minutiae of the Holocaust and its prolegomena that, in part, intensified the anti-Semitism of the perpetrators" (87, emphasis mine - V.T.).

In this analysis, ordinary people may be compelled by a given situation (involving obedience to authority) to commit a distasteful act, which would fit into Milgram's experimental findings. And that act, when considered retrospectively, redefines the self in the mind of the perpetrator. Thus, for example, a person with latent anti-Semitic feelings (or even with no such feelings at all) may have been pressured by some authority source in one way or another to support or even commit anti-Semitic aggression (at a Nazi rally, at work, in the street). But once that happens, the perpetrator's identity begins to change along the lines of: "Aha! Now I am the kind of person who does such things." When several such actions occur, a person's sense of self may change radically, leading to new behaviors and ideas which gradually cease to be foreign to us. We need to maintain a coherent picture of our identities, which would explain this circular process of self-redefinition. To be consistent we begin to act in line with our new identity, sucked in more and more into an evil vortex that refuses to let us go.

If this self-perception theory is applied to Lenz's policeman, we can offer a possible explanation of Jens' gradual change in attitude toward his task and toward the painter. Part of Jens' initial self-definition is that he is not the sort of person who betrays friends and neighbors. We learn that Jens is not just the local policeman but someone who socializes with the painter's family:

Nimmst du Tee oder Schnaps, Jens, fragte die Frau des Malers, mir ist nach Schnaps. Mein Vater winkte ab. Nichts, Ditte, sagte er, heute nichts, und 
er setzte sich nicht wie sonst auf den Fensterstuhl, trank nicht wie sonst, sprach nicht wie sonst. [...] Jedenfalls, ließ inn das, was er zu tun hatte, nicht gleichgültig (Lenz: 24).

The policeman is not "gleichgültig" because, according to his present selfdefinition, his task constitutes an antisocial act in the context of interpersonal bonding, hence his nervousness and discomfort. However, as Jens' need to obey authority pushes him into betraying Nansen after all, the policeman redefines himself in a way that incorporates the betrayal and maintains a coherent sense of self. This is why he eventually loses his nervousness, continues the betrayal with more and more energy and even condemns the painter for his disobedience to authority. If no change in Jepsen's selfdefinition took place, he would remain reluctant in the enforcement of the painting interdiction to the very end. In this connection Gordon J. A. Burgess writes: "Im Laufe der Geschichte ändert Siggis Vater seine Konzeption von dem, was er für seine Pflicht hält. Zunächst erfüllt [Jepsen] seine 'Pflicht', was der Malverbot für Nansen anbetrifft, nur widerwillig [...] Aber allmählich wird seine 'Pflicht', das Malverbot zu überwachen zu fixen Idee" (30-31). Therefore, we can imagine a transition in Jens' mind from "I don't do such things" to "I do such things." Todd Kontje's sums up the phenomenon of self-redefinition in Lenz' work:

The individual is not the source of potential new activity in the world, but rather a superfluity which will only obtain meaning upon the assumption of a fixed role in a finished world. [...] The individual is therefore the passive product of the totality of his experiences. [...] Thus, the process of determination which molds the passive individual from without marks simultaneously the gradual construction of a new world within" (459, emphasis mine - V.T.)

This essay was started with a comparison between Lenz' fictional policeman who obeys authority and a real Swiss policeman, Paul Grueninger, who disobeyed. Just as it was argued above that Jens Jepsen is presented as rather dull and apolitical, so too 
Grueninger had no apparent interest in politics, nor for that matter did he have an affinity for any ideology [...] although he was very attentive to his responsibilities as chief of police, especially his duty to protect people against crime. In a way, protecting the refugees from their persecutors was an extension of this understanding of his duties. What he was doing at the Swiss border, to the extent possible, was protecting refugees from the criminal acts of their persecutors" (Rochat: 107).

Thus, we have two individuals - a literary character and a real person - who are very much taken with the notion of duty but act upon their respective understandings in opposite ways. In order to account for this, let us turn to the work of the psychologist Lawrence Kohlberg, a Yale colleague of Milgram, who took an interest in the Milgram's findings.

According to Kohlberg, humans in many societies pass through a set of stages as they develop morally. The first stage corresponds to early childhood and is based on a definition of morality in terms of punishment. Thus, a young child will steal a cookie as long as no one sees it. The second stage is based on exchange, i.e., one will treat another person well only if something can be received in exchange for the good treatment. These two stages are presocial, and adults who stagnate at this point in their moral development are often con-men or criminals. As the individual grows, progression to stage three takes place. Here group approval is what determines right and wrong. Thus, whatever one's in-group may be (a tribe, a gang, a clique, a team or a school), the group's attitude will guide the individual's actions. This is the beginning of society, but only a rudimentary and usually small social unit can function at stage three. The next stage is of greatest interest to us for two reasons: most adults stop developing here (Kohlberg: 46) and Jens Jepsen in Deutschstunde epitomizes stage four: "There is an orientation toward authority, fixed rules, and the maintenance of social order. Right behavior consists of doing one's duty, showing respect for authority, and maintaining the given social order for its own sake" (Kohlberg: 18). 
Kohlberg points out that stage four thinking is normally uncritical and boils down to observing the law. Therefore, this type of moral reasoning is normally what characterizes the proverbial "upstanding citizen" and yet, under certain circumstances, can lead to terrible deeds committed by ordinary people. This is illustrated in Lenz' novel by a conversation between Okko Brodersen, the town's mailman, and Jens Jepsen. The mailman points out Max Nansen's greatness as a painter and appears to reject the reasons behind the interdiction at least on that basis. But Jens counters with the follwing example of stage four thinking: "Wer seine Pflicht tut, der braucht sich keine Sorgen zu machen" (Lenz: 102). There is no need for Jens to analyze the law or the nature of the authority behind the law because the law is self-serving - like a part of nature. It is from the letter rather than the spirit of the law that Jepsen derives his "upstanding citizen" concept. This is why making the transition to post-Nazi rule in 1945 is so easy for Lenz' policeman:

Drei Monate nur hatte es keinen Polzeiposten Rugbüll gegeben, doch dann tauchte er wieder auf mit seinem trockenen Gesicht und den schlecht sitzenden Hosen und übernahm sein Amt mit einer Selbsverständlichkeit, als hätte er keinen erzwungenen, sondern einen freiwilligen Urlaub gemacht (Lenz: 343).

As long as there is authority (Nazi or not), it must obeyed. And the extent to which this was the norm for millions under Hitler can be glimpsed from the following comment that Jens makes to the painter in response to Nansen's rejection of the painting interdiction: "Du bist so, sagte mein Vater, du allein. Es gibt andere, viele andere, die sich an die allgemeine Ordnung halten - du brauchst deine persönliche Ordnung" (Lenz: 168). ${ }^{3}$ Albrecht Weber goes even further and argues that most of the characters around the Jepsen family "gehen pflichtbewusst ihrem Tageslauf nach in der Überzeugung, dass die Regierung, ebenso pflichtbewusst, schon die richtigen Entscheidungen fällen werde. Zu selbstständigem Handeln, zu Kritikfähigkeit ist die Überzahl der geschildrerten Personen nicht fähig" (78, cf. Murdoch and Read: 74). The point 
is that in a totalitarian regime the system encourages the individual to stop his or her moral functioning at stage four. One can even argue that this stage is the perfect totalitarian state of being.

Max Nansen epitomizes moral thinking beyond stage four as outlined by Kohlberg: "Er handelt aus Pflicht, aus seiner inneren Verpflichtung. Deswegen wehrt er sich gegen von außen auferlegte, sogennante Pflicht" (Weber: 89, cf. Murdoch and Read: 62). Relatively few people in any given society reach stage five, but if they do, they define right and wrong in terms of the way a given action will affect the well-being of society. Kohlberg views stage five as a conscious social contract: "Right action tends to be defined in terms of general individual rights and in terms of standards that have been critically examined and agreed on by the whole society" (18). Thus, the law is obeyed only if it corresponds to this critical view of morality. When Nansen confronts Jens Jepsen, the painter attempts in vain to explain this type of thinking to the policeman: "Laß uns daran denken, was in zwei, drei Jahren sein wird, vielleicht noch früher. Wenn wir zu etwas verpflichtet sind, dann dazu: vorauszusehen. [...] Wer zwingt uns, engültige Urteile zu fällen?" (169). Nansen is trying to make Jens think about the reasons and persons behind the painting interdiction but, needless to say, does not get through the impenetrable wall of stage four morality.

If, however, Nansen were addressing the Swiss policeman Paul Grueninger, he would undoubtedly encounter a very different reaction. As Rochat points out (see quoted passage above), Grueninger's understanding of duty amounted to protecting those exposed to a malevolent force. In fact, Kohlberg argues that there is even a stage six, the ultimate one in the moral development process, and extremely few people ever reach it. According to Kohlberg's scheme it can be assumed that Grueninger did function at something like stage six by disobeying an unjust law. Kohlberg's example of this mindset is Martin Luther King as is evident from the latter's famous "Letter from a Birmingham Jail": 
"One has the moral responsibility to disobey unjust laws. An unjust law is a human law that is not rooted in eternal law and natural law. [...] An unjust law is a code that a numerical or power majority group compels a minority group to obey but does not make binding on itself" (quoted in Kohlberg: 43). Essentially, stage six is about human rights and the assumption that every moral decision must be guided not just by its impact on society in general, but also by the way a given individual human being is affected. Some have pointed out that the difference between stages five and six is vague, but what interests us here is that in Lenz' Deutschstunde and in the drama of Paul Grueninger, we witness the confrontation between stage-four morality and the ethics of stage $5 / 6$.

There is a fascinating connection between Kohlberg's theory and Milgram's experiment. Using a complex questionnaire intended for establishing a given person's moral profile, Kohlberg interviewed some of Milgram's subjects in order to place them on the six-point moral scale (Milgram: 205). What he found relates directly to the case of Paul Grueninger: "75 percent of those at Stage 6 quit or refused to shock the victim, as compared to only 13 percent of all the subjects at lower stages" (Kholberg: 44-5). However, as Kohlberg argues, even people located at the lower stages of moral development still possess elements of higher-stage thinking (46). This normally does not translate into action, but the higher moral potential is there in all of us - even in Jens Jepsen. This is evident not only from the reservations that the policeman initially manifests when the painting interdiction comes in, but also from another dilemma that he faces in Deutschstunde. At one point Jens considers what to do if his older son Klaas - who has deserted from the German army - shows up at the family home: "Ich weiß nicht, sagte mein Vater, ich weiß nicht was ich tun soll, aber sie [Gudrun] darauf: Du weißt hoffentlich, was von dir erwarted wird" (95). Even though Jens knows very well that Klaas must be reported to the authorities, the dutiful policeman hesitates - "ich weiß nicht was ich tun soll." This indicates an embryonic 
sense of decency and personal loyalty, i.e., values beyond merely stage four. For a brief instant Lenz' marionette-like policeman seems to regain his humanity, but then he quickly caves in and becomes an automaton under the overwhelming weight of social structures. Given the appropriate prod by his wife, Jens accepts that Klaas must be reported to the Nazi authorities, i.e., he does what most of Milgram's subjects did in spite of their inner conflict. Authority wins out in the end, and everyone loses.

One may be tempted to argue that Lenz demonstrates obedience to authority in an authoritarian society. Presumably things should be different in a democracy. However, given that Milgram's study dealt with subjects in a democratic society, the obedience urge seems to be more than just a political issue. In fact Milgram argues that it is essential in any social system: "The formation of hierarchically organized groupings lends enormous advantage to those so organized in coping with dangers of the physical environment, threats posed by competing species, and potential disruptions from within" (123-4). Our point of focus is "disruptions from within" and the way complex social systems deal with this potential for imbalance. Although authoritarianism is a common response to this potential, Milgram is careful to point out that atrocities were committed by American soldiers in the My Lai massacre during the Vietnam war (183-6). That too was a form of obedience to authority even though it took place within an army that represented a pluralistic society. If we add to this the recent cases of prisoner abuse in Baghdad's Abu Ghraib prison, we can argue that the portrait of German society painted in Deutschstunde appears to go beyond an indictment of Nazism or a trait of the German mentality. To quote Brian Murdoch and Malcolm Read, "the moral of the story may apply equally to any society and to regard it, and the problem of duty, simply as the German virtue that became the German vice, is to assume a moral certainty about ourselves that Lenz warns against" (74). 
The implications of this are rather dismal. Neither the German novelist nor the American psychologist (Milgram) offers an optimistic solution to the question of how to balance the obedience urge and conscious morality. Kohlberg does suggest that deep down everyone carries the seeds of advanced moral thinking, but his findings suggest that these seeds sprout in a minority of individuals. And yet, the very existence of this minority can be seen as a beacon of hope as well as an inspiring ideal. The urge to question is just as inherent to the human psyche as the need to obey. This is why for a thousand Jens Jepsens there is always a Paul Grueninger, and as long as this ratio remains relatively constant, one will be able to affirm that there is more to the human condition than life on an anthill.

\section{Notes:}

2. Related to Milgram's study was the famous Stanford Prison Experiment where students were asked to play the roles of prison guards and prisoners in a mock prison. The roles influenced everyone to such an extent that prisoner abuse (sleep deprivation, verbal humiliation, isolation, general sadism and physical violence), a revolt by the prisoners and great distress on the part of the participants lead to the premature termination of the experiment. Normal students ended up acting out abominable roles in spite of their own convictions and values. Philip Zimbardo, the director of the experiment, sums up the point of the study in a way that echos Milgram's conclusions: "SPE has challenged people's views that behavior is primarily under the influence of dispositional factors, which is the view promoted by much of psychology, psychiatry, religion, and law" (212). Instead, situational motivation must be taken into consideration when human behavior is evaluated.

3. The uniqueness of Nansen's morality in wartime Germany is recognized by Jens Jepsen's son Klaas, a deserter from the army who is on the run. Referring to the painter, Klaas says the following to Siggi: "Er ist der einzige, sagte mein Bruder, er wird mich verstecken, das weiß ich" (Lenz: 107). 


\section{Works Cited}

Burgess, Gordon J.A. "Pflicht und Verantwortungsgefühl: Es waren Habichte in the der Luft, Deutschstunde, Ein Kriegsende." In Ed. Rudolf Wolff. Siegfried Lenz. Werk und Wirkung. Bonn: Bouvier Verlag Herbert Grundmann, 1985: 26-34.

Collins, Barry E. and Laura Ma. "Impression Management and Identity Construction in the Milgram Social System." In Ed. Thomas Blass. Obedience to Authority: Current Perspectives on the Milgram Paradigm. London: London: Lawrence Erlbaum Associates, Publishers, 2000: 61-90.

Kohlberg, Lawrence. The Philosophy of Moral Development. New York: Harper and Row, 1981.

Kontje, Todd. "Captive Creator in Siegfried Lenz's Deutschstunde: Writer, Reader and Response." The German Quarterly, Vol. 53, No. 4 (Nov., 1980), 458-66.

Milgram, S. Obedience to authority: An experimental view. New York: Harper \& Row, 1974.

Murdoch, Brian and Malcolm Read. Siegfried Lenz. London: Oswald Wolff, 1978.

Paslick, Robert H. "Narrowing the Distance: Siegfried Lenz's Deutschstunde." The German Quarterly, Vol. 46, No. 2 (Mar., 1973), 210-218.

Rochat, Françoit. "Captain Paul Grueninger: The Chief of Police Who Saved Jewish Refugees by Refusing to Do His Duty." In Ed. Thomas Blass. Obedience to Authority: Current Perspectives on the Milgram Paradigm. London: Lawrence Erlbaum Associates, Publishers, 2000: 91-110.

Weber, Albrecht. Siegfried Lenz. Deutschstunde. München: Oldenburg Verlag, 1975.

Zimbardo, Philip. "Reflections on the Stanford Prison Experiment: Genesis, Transformations, Consequences." In Ed. Thomas Blass. Obedience to Authority: Current Perspectives on the Milgram Paradigm. London: Lawrence Erlbaum Associates, Publishers, 2000: 193-237. 